\title{
Characterization of the Growth of
}

\section{Pseudomonas putida LP on Lipoate and its Analogues: Transport, Oxidation, Sulphur Source, and Enzyme Induction}

\author{
By J. C. H. SHIH,* MARTHA L. ROZO, L. D. WRIGHT AND \\ D. B. MCCORMICK \\ Division of Nutritional Sciences and Section of Biochemistry, Molecular and \\ Cell Biology, Cornell University, Ithaca, New York 14850, U.S.A.
}

(Received 17 June 1974; revised 2 September 1974)

\begin{abstract}
SUMMARY
Pseudomonas putida LP, which grows on lipoate, $\mathrm{NH}_{4} \mathrm{NO}_{3}$ and mineral salts, converts most of the organic substrate to bisnor-lipoate (1,2-dithiolane-3-propanoic acid) and acetyl-CoA. D-, L-, or DL-lipoate serve equally well as carbon and sulphur sources. There was no growth on or bacterial oxidation of the chemically synthesized bisnor- or tetranor-(I,2-dithiolane-3-carboxylic acid) chain-shortened analogues, but these, as well as lipoate, could supply the sulphur needed for growth when acetate was provided as the sole source of carbon. The uptake of lipoate by the bacterium is very slow and non-inducible, while the uptake of acetate is faster than octanoate. The oxidation of octanoate is more rapid and extensive than that of lipoate. Levels of acyl-CoA synthetase are not affected by the source of carbon, but activities of isocitrate lyase and malate synthase are higher when the cells are grown in acetate, octanoate or lipoate and lower when glucose is the carbon source. The glyoxylate cycle is induced to facilitate utilization of acetyl-CoA derived from lipoate, which is also degraded to water-soluble catabolites that yield the much smaller amount of sulphur required for growth.
\end{abstract}

\section{INTRODUCTION}

Although the principal biochemical function of lipoic (thioctic) acid in $\alpha$-keto acid dehydrogenases is understood, little was known concerning the metabolic fate of this compound. An organism identified as Pseudomonas putida LP was isolated and adapted to grow in a synthetic medium, which contained $0.4 \%(\mathrm{w} / \mathrm{v})$ lipoic acid as the sole source of carbon, sulphur and energy. One major catabolite was identified as bisnor-lipoic (I,2-dithiolane-3propanoic) acid, indicating at least partial $\beta$-oxidation of the side chain (Shih, Wright \& McCormick, 1972).

We have now studied uptake, oxidation and sulphur utilization of lipoic acid and its chainshortened analogues by this lipoate-degrading pseudomonad. To ascertain the existence of pathways for $\beta$-oxidation and the glyoxylate cycle in the pseudomonad grown on lipoate, some relevant enzyme activities have also been determined.

* Present address: Department of Biochemistry, School of Chemical Sciences, University of Illinois, Urbana, Illinois 6I80r, U.S.A. 


\section{METHODS}

Materials. DL-Lipoic and octanoic (caprylic) acids were purchased from Sigma. Monomethyl adipate, monomethyl succinate and $\gamma$-butyrolactone were from Aldrich Chemical Co., Cedar Knolls, New Jersey, U.S.A. The $\left[\mathrm{I}, 6{ }^{1{ }^{14}} \mathrm{C}_{2}\right]$ adipic acid was obtained from Amersham/Searle Corp., Arlington Heights, Illinois, U.S.A. $\left[{ }^{\mathrm{I}}{ }^{14} \mathrm{C}\right]$ octanoate (Na salt) and $\left[{ }^{1-}{ }^{14} \mathrm{C}\right]$ acetate (K salt) were purchased fiom New England Nuclear Corp., Boston, Massachusetts, U.S.A.

Chemical syntheses of $\left[\mathrm{I}, 6-{ }^{14} C_{2}\right]$ lipoic acid, analogues and stereoisomers. $\mathrm{DL}\left[\mathrm{I}, 6-{ }^{14} \mathrm{C}_{2}\right]-$ lipoic acid was synthesized from $\left[\mathrm{I}, 6-{ }^{14} \mathrm{C}_{2}\right]$ adipic acid by the method of Pritchard, McCormick \& Wright (1970), except that methyl instead of ethyl esters of synthetic intermediates were used. The commercial, unlabelled DL-lipoic acid was recrystallized from cyclohexane. Bisnor-lipoic acid was synthesized from monomethyl succinate after the method of Kumagaya \& Kasuga (1963). Tetranor-lipoic (I,2-dithiolane-3-carboxylic) acid was synthesized from $\gamma$-butyrolactone according to Claeson (1955) as modified by Wladislaw (1957). The D- and L-forms of lipoic acid were prepared by the method of Acker \& Wayne (1957). The optical rotatory properties of the prepared stereoisomers were measured in benzene solutions with a Jasco optical rotatory dispersion recorder, model ORD/UF-S (Japan Spectroscopic Co., Tokyo, Japan). The optical rotations are $[\alpha]_{D}^{22}=+110^{\circ}\left(+9 \mathrm{I}^{\circ}\right.$ reported by Acker \& Wayne, I957) for the D-isomer, and $[\alpha]_{D}^{22}=-55^{\circ}\left(-63^{\circ}\right.$ reported by Acker \& Wayne, 1957) for the L-isomer. These isomers were used to examine the substrate stereospecificity for the bacterial growth.

Organism and culture conditions. The preparation of medium, which contained $0.4 \%$ (w/v) lipoate, and the culture conditions for the isolated $P$. putida LP were as reported previously (Shih et al. 1972), except that the basal medium was slightly modified. The basal medium contained: $\mathrm{NH}_{4} \mathrm{NO}_{3}, 2 \cdot 0 \mathrm{~g} ; \mathrm{MgCl}_{2} \cdot 6 \mathrm{H}_{2} \mathrm{O}, 0.3 \mathrm{~g} ; \mathrm{CaCl}_{2} \cdot 2 \mathrm{H}_{2} \mathrm{O}, 3 \cdot 0 \mathrm{mg} ; \mathrm{FeCl}_{2}$. ${ }_{4} \mathrm{H}_{2} \mathrm{O}, 3.0 \mathrm{mg}$; sulphur-free trace element solution, $0.1 \mathrm{ml}$; molybdate solution $(27.7 \mathrm{mg}$ $\mathrm{Na}_{2} \mathrm{MoO}_{4} \cdot 2 \mathrm{H}_{2} \mathrm{O} / 1$ distilled water), $\mathrm{r} \cdot 0 \mathrm{ml} ; \mathrm{KH}_{2} \mathrm{PO}_{4} / \mathrm{K}_{2} \mathrm{HPO}_{4}(\mathrm{pH} 6 \cdot 8$ ), $0.004 \mathrm{~mol}$; distilled water to I 1. Sulphur-free trace element solution contained $(\mathrm{mg} / \mathrm{ml}): \mathrm{SnCl}_{2} \cdot 2 \mathrm{H}_{2} \mathrm{O}, 28$; $\mathrm{MnCl}_{2} \cdot 4 \mathrm{H}_{2} \mathrm{O}, 388 ; \mathrm{NiCl}_{2} \cdot 6 \mathrm{H}_{2} \mathrm{O}, 55 ; \mathrm{LiCl}, 28 ; \mathrm{CuCl}_{2} .2 \mathrm{H}_{2} \mathrm{O}, 55 ; \mathrm{ZnCl}_{2}, 34 ; \mathrm{H}_{3} \mathrm{BO}_{3}, 6$ I 2 ; $\mathrm{AlCl}_{3} .6 \mathrm{H}_{2} \mathrm{O}$, I08; $\mathrm{CoCl}_{2} .6 \mathrm{H}_{2} \mathrm{O}, 55 ; \mathrm{KI}, 28 ; \mathrm{KBr}, 28$; distilled water to I 1 . These modifications made no apparent difference to bacterial growth.

Bacterial growth on analogues and steroisomers. Medium containing $0.2 \%(\mathrm{w} / \mathrm{v})$ bisnorlipoate or tetranor-lipoate instead of lipoate was prepared in the same manner as the lipoate medium. Bacteria were inoculated from a culture grown on lipoate and incubated under the same conditions, by shaking at $140 \mathrm{rev}$. $/ \mathrm{min}$ at $30^{\circ} \mathrm{C}$ in a gyratory shaker (New Brunswick Scientific, New Jersey, U.S.A.) (Shih et al. 1972). The increase in turbidity, measured by extinction at $650 \mathrm{~nm}$ with a Beckman DU spectrophotometer (Beckman Instrument Co., Wakefield, Massachusetts, U.S.A.), indicated bacterial growth. Dry weights were obtained on centrifuged, lyophilized cells.

Two types of experiment were carried out to compare the growth of the bacterium on resolved $\mathrm{D}$ - and L-lipoic acid. One compared the growth when the bacteria were incubated in media containing $0.4 \%(\mathrm{w} / \mathrm{v}) \mathrm{D}-, \mathrm{L}-$, or DL-lipoic acid. The other compared the remaining radioactivity, as well as growth, in media that contained $0 \cdot 2 \%(\mathrm{w} / \mathrm{v}) \mathrm{DL}-\left[{ }^{14} \mathrm{C}\right]$ lipoic acid with that containing $0.2 \% \mathrm{D}$ - or L-lipoic acid. Radioactivity remaining in the medium was measured as described previously (Shih et al. 1972).

Column chromatographic separation of lipoate and the bisnor- and tetranor-analogues. Sephadex LH-20 (Pharmacia Fine Chemicals, Piscataway, New Jersey, U.S.A.) column 
chromatography was used to separate lipoic, bisnor-lipoic, and tetranor-lipoic acids (Shih, Williams, Wright \& McCormick, 1974). The same column was used to separate the principal catabolite, bisnor-lipoic acid, from the lipoate medium after two days of growth in a $\left[{ }^{14} \mathrm{C}\right]-$ lipoate medium. A concentrated chloroform extract of the acidified medium (Shih et al. 1972) was eluted with chloroform at a flow rate of $\mathrm{I} \mathrm{ml} / \mathrm{min}$ and the effluent collected in Io $\mathrm{ml}$ fractions. The presence of $\left[{ }^{14} \mathrm{C}\right]$ lipoic acid, $\left[{ }^{14} \mathrm{C}\right]$ bisnor-lipoic acid, and other catabolites in the effluent was detected and estimated, both by the extinction at $330 \mathrm{~nm}$ with the Beckman DU spectrophotometer, and by the radioactivity of $0.5 \mathrm{ml}$ samples in LSC complete toluene counting fluid (Yorktown Research Inc., New York, U.S.A.) measured with a Packard liquid scintillation spectrometer, model 3375 (Packard Instrument Co., Downers Grove, Illinois, U.S.A.).

Uptake of lipoate, octanoate and acetate. After two days growth on lipoate or glucose, bacteria were harvested by centrifuging at $0{ }^{\circ} \mathrm{C}$, washed with $0 \cdot 15 \mathrm{M}-\mathrm{NaCl}$, and resuspended in $0.9 \%(\mathrm{w} / \mathrm{v}) \mathrm{NaCl}$ at $0{ }^{\circ} \mathrm{C}$ to an $\mathrm{E}_{650}$ of 4.8 . The reaction mixture for measuring uptake contained $0.9 \mathrm{ml}$ of the cell suspension, $5.85 \mathrm{ml}$ Cohen-Rickenberg medium $\mathrm{pH} 7.3$ (Cohen \& Rickenberg, I956), $0.12 \mathrm{ml}$ chloramphenicol $(2 \mathrm{mg} / \mathrm{ml})$, and $0.03 \mathrm{ml}$ of $50 \%$ glycerol. The mixture was pre-incubated at room temperature (approximately $25^{\circ} \mathrm{C}$ ) and then $0.6 \mathrm{ml}$ of $0.5 \mathrm{~mm}{ }^{14} \mathrm{C}$-substrate added. At timed intervals, I ml samples were filtered on Millipore HA membrane (pore size $0.45 \mu \mathrm{m}$ ), followed by washing with Io $\mathrm{ml}$ of an ice-cold solution of $0.0 \mathrm{I}$ M-tris, $0 . \mathrm{I} 5 \mathrm{M}-\mathrm{NaCl}$ and $0.5 \mathrm{mM}-\mathrm{MgCl}_{2}$ at $\mathrm{pH} 7.3$. The filters were removed, air-dried under a lamp, placed in Io $\mathrm{ml}$ toluene scintillation fluid, and the radioactivity was determined in the liquid scintillation spectrometer.

Bacterial oxidation of lipoate, lipoate analogues and octanoate. A Gilson Oxygraph (Gilson Medical Electronics, Middleton, Wisconsin, U.S.A.) was used to measure the bacterial uptake of dissolved oxygen on lipoate, lipoate analogues and octanoate. Experimental procedures were as described by Shih et al. (1972). After two days growth, bacteria were harvested, washed, aerated and resuspended in basal medium $(\mathrm{I} \%, \mathrm{w} / \mathrm{v})$, then incubated with the substrates. The rate of oxygen uptake was calculated from the recorded oxygraph.

Production of ${ }^{14} \mathrm{CO}_{2}$ from $\left[{ }^{14} \mathrm{C}\right]$ lipoate and $\left[{ }^{14} \mathrm{C}\right]$ octanoate. Bacteria were harvested after two days growth in lipoate medium, washed twice with basal medium, resuspended in $0.05 \mathrm{M}-$ phosphate buffer $\mathrm{pH} 7$ to an $E_{650}$ of $\mathrm{I} \cdot 0$, and used either intact or after sonication for $30 \mathrm{~s}$ with an ultrasonic cell disrupter (Heat Systems-Ultrasonics, Inc., Plainview, New York, U.S.A.) which was adjusted to a meter reading of 90 while the temperature was kept at 0 to $5{ }^{\circ} \mathrm{C}$. The production of ${ }^{14} \mathrm{CO}_{2}$ from $\left[\mathrm{I}, 6{ }^{-14} \mathrm{C}_{2}\right]$ lipoate and $\left[\mathrm{I}^{14} \mathrm{C}\right]$ octanoate was determined by the method of Yang \& McCormick ( 1967 ), by mixing $3.5 \mathrm{ml}$ cell suspension, intact or sonicated, with final concentrations of $0.1 \mathrm{mM}$ each of ATP, CoA and $\mathrm{MgCl}_{2}$, and $0.0 \mathrm{I} \mathrm{mM}-\left[\mathrm{I}, 6-{ }^{14} \mathrm{C}_{2}\right]$ lipoate or- $\left[\mathrm{I}-{ }^{14} \mathrm{C}\right]$ octanoate in a total volume of $5 \mathrm{ml}$. The reaction mixtures were incubated at $30^{\circ} \mathrm{C}$ in $50 \mathrm{ml}$ Erlenmeyer flasks, which were stoppered with rubber septa (Kontes Co., Vineland, New Jersey). Appended to each rubber septum was a polypropylene centre well containing a wick of Whatman No. I filter paper and $0.5 \mathrm{ml}$ of a I ml solution of Hydroxide of Hyamine (Packard Instrument Co.), a high-molecular-weight quaternary ammonium hydroxide in methanol. The reactions were terminated at intervals by injecting I $\mathrm{ml}$ of $20 \%$ trichloroacetic acid into the incubation mixture. The ${ }^{14} \mathrm{CO}_{2}$ trapped in the alkaline solution in the centre well was determined by measuring the radioactivity with $5 \mathrm{ml}$ toluene scintillation fluid in the liquid scintillation spectrometer.

Test of sulphur sources. When the bacterium was grown in medium containing lipoate as the only sulphur compound, some lipoate must have been degraded to meet the sulphur requirement. An experiment was designed to find out whether a small amount of lipoate 
would enhance the growth of bacteria incubated in an otherwise sulphur-free medium with acetate as the sole carbon source. Similar experiments with other sulphur-containing substances, including lipoate analogues, cystine, cysteine and sodium sulphate, were carried out simultaneously.

All media contained $0.2 \%(\mathrm{w} / \mathrm{v})$ each of acetate and ammonium nitrate, except for two controls: one with only $0.2 \%(\mathrm{w} / \mathrm{v})$ acetate with $0.2 \%(\mathrm{w} / \mathrm{v})$ ammonium sulphate, and the other with only $0.4 \%(\mathrm{w} / \mathrm{v})$ lipoate and $0.2 \%(\mathrm{w} / \mathrm{v})$ ammonium nitrate. The following additions $(\%, w / v)$ were made to the experimental media: 0.009 lipoate, 0.007 bisnorlipoate, 0.006 tetranor-lipoate, $0.0 \mathrm{I}$ L-cysteine, $0.0 \mathrm{I}$ L-cystine, or $0.0 \mathrm{I} 2$ sodium sulphate. Under such conditions, all media contained $0.0027 \%(\mathrm{w} / \mathrm{v})$ sulphur. To avoid oxidation and decomposition, all media were sterilized by filtration through autoclaved Millipore filters ( $0.45 \mu \mathrm{m}$ pore size) into autoclaved flasks.

To determine whether the derivation of sulphur from lipoate and its analogues is the limiting step for growth, the bacterium was also incubated in a medium containing sufficient sulphate, in addition to lipoate or its analogues. Ammonium sulphate $(0.02 \%, \mathrm{w} / \mathrm{v})$ as both sulphur and nitrogen source was added to the medium, which contained lipoate, bisnorlipoate or tetranor-lipoate.

Preparation of cell-free extracts. Bacteria were grown in the media containing $(\%, w / v)$ : 0.4 lipoate, 0.4 octanoate, 0.2 acetate or 0.4 glucose as the sole carbon source, and 0.2 ammonium sulphate as the source of nitrogen and sulphur, except for the lipoate medium, which contained 0.2 ammonium nitrate as the nitrogen source. Cells were harvested in the late exponential phase of growth by centrifuging at $15000 \mathrm{~g}$ for $15 \mathrm{~min}$ and washed twice with the basal medium. The washed cell masses were weighed and stored at $-15{ }^{\circ} \mathrm{C}$.

When required, cell pastes were thawed and suspended in $0^{\circ} \mathrm{I}$ M-sodium phosphate buffer pH 6.8 containing 0.0 I M-mercaptoethanol to make a concentration of $80 \mathrm{mg}$ cells $/ \mathrm{ml}$ of buffer. The cell suspensions, as $5 \mathrm{ml}$ portions in continuous flow Rosett cells (small, fourside-armed flasks for fast cooling; Branson Sonic Power, Danbury, Connecticut, U.S.A.) were sonicated for $20 \mathrm{~min}$ with the ultrasonic cell disrupter (Heat Systems-Ultrasonics), which was adjusted to a meter reading of 80 . The temperature of cell suspensions was kept at 0 to $5{ }^{\circ} \mathrm{C}$ with an ice-water cooling bath. The broken-cell homogenate was centrifuged at $20000 \mathrm{~g}$ for $30 \mathrm{~min}$, and the resultant supernatant used to determine enzymic activities.

Determination of enzymic activities. Acyl-CoA synthetase [EC. 6.2.1.2, acid CoA ligase (AMP)] in the crude extracts was determined by the amount of hydroxamate produced (Overath, Pauli \& Schairer, I969), with octanoate as the substrate and acetohydroxamate (Aldrich Chemical Co.) as the standard. Isocitrate lyase (EC. 4. I.3. I, L-isocitrate glyoxylatelyase) activity was determined by the method of Dixon \& Kornberg (I959), and malatesynthase [EC. 4.I.3.2, L-malate glyoxylate-lyase (CoA-acetylating)] by the method of Eggerer \& Klette (I967). The specific activities of the three enzymes are defined as number of nmoles of product produced (acyl-CoA synthase and isocitrate lyase) or substrate changed (malate synthase) per minute per mg protein.

Protein determinations. The amounts of protein in the cell-free extracts or cell preparations were determined by the method of Lowry, Rosebrough, Farr \& Randall (I95I). 


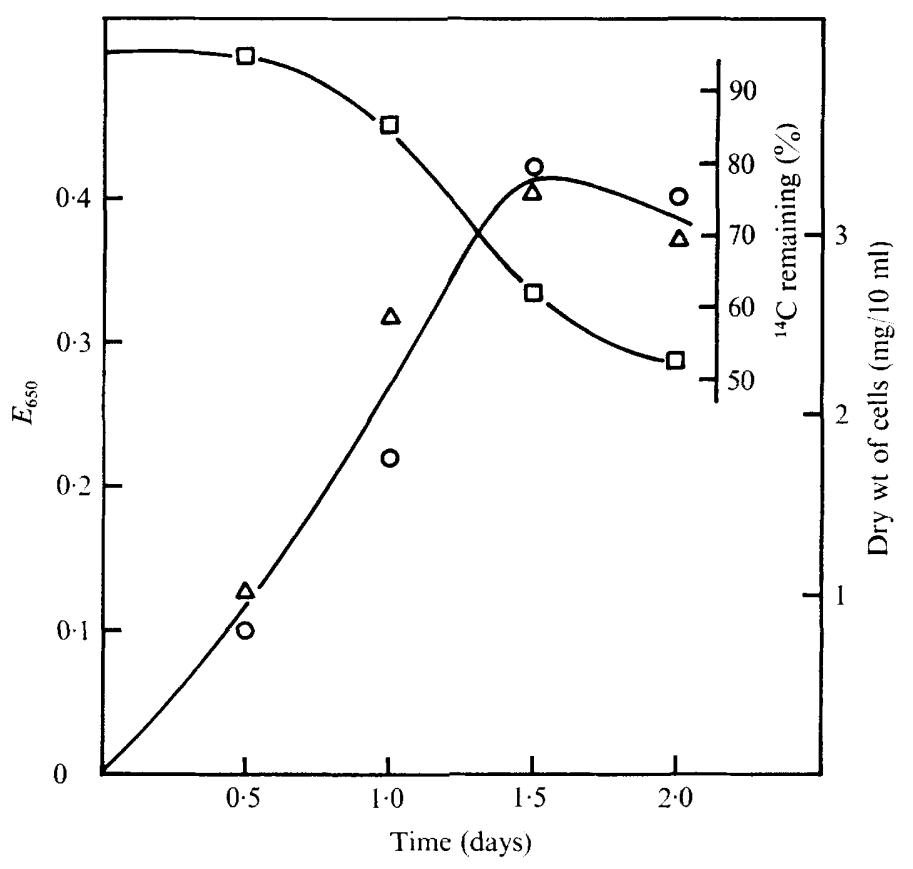

Fig. I. Growth, followed by extinction $(O)$ and dry weight of cells $(\triangle)$, and the disappearance of radioactivity $(\square)$ in a $0.4 \%(\mathrm{w} / \mathrm{v})\left[1,6^{-14} \mathrm{C}_{2}\right]$ lipoate medium.

\section{RESULTS}

\section{Growth on lipoate analogues and stereoisomers}

The isolated pseudomonad does not grow in the media containing $0.2 \%(\mathrm{w} / \mathrm{v})$ bisnorlipoate or $0.2 \%(\mathrm{w} / \mathrm{v})$ tetranor-lipoate. The technique of Shih et al. (1972), by which cells are adapted to grow better on lipoate through reducing a supplementary carbon source such as acetate, was unsuccessful with these analogues.

There is no significant difference in growth with either $D$ - or L-isomer. The growths are still the same when half of the substrates are replaced by DL- $\left[{ }^{14} \mathrm{C}\right]$ lipoate, and the rates and extents of loss of ${ }^{14} \mathrm{C}$-radioactivity are also about the same in the three kinds of media (Fig. I). Therefore, it is concluded that stereospecificity does not play an important role in the catabolic release of sufficient carbon, such as it may in the coenzyme function where only the natural D-lipoic acid operates.

\section{Column chromatography of the chloroform extract of utilized medium}

Column chromatography of the chloroform extract of a $\left[{ }^{14} \mathrm{C}\right]$-lipoate culture medium after two days of growth (Fig. 2) revealed a single main peak of both absorbance and radioactivity, identified as bisnor-lipoic acid from its mobility in the column as well as by paper chromatography (Shih et al. 1974). A small peak closely preceding the main one was lipoic acid. Significant amounts of other metabolites were not detected in the chloroform extract of the medium. Chloroform extracted approximately $80 \%$ of the total radioactivity remaining in the culture medium after two days' growth. The $20 \%$ of total radioactivity remaining in the aqueous phase contained several anion-exchangeable catabolites of unknown structure. 


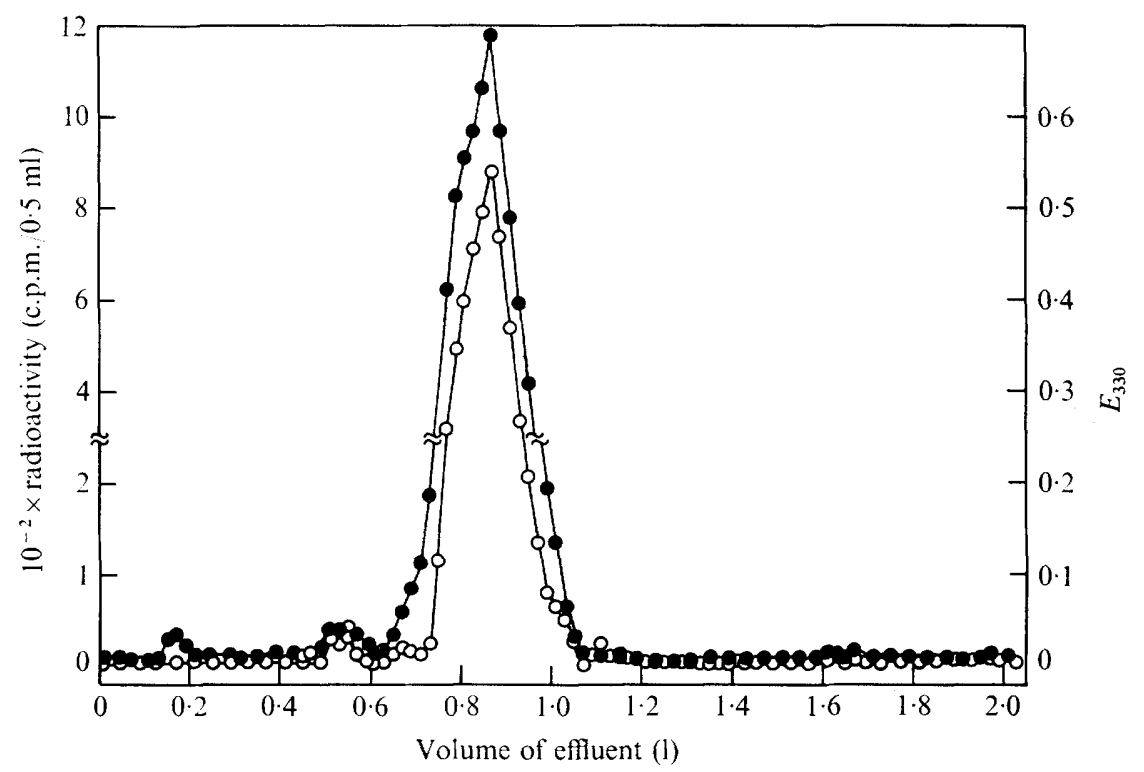

Fig. 2. Sephadex LH-20 column chromatography of the chloroform extract of a two-day-old culture medium, which originally contained $0.4 \%(\mathrm{w} / \mathrm{v})\left[{ }^{14} \mathrm{C}\right]$ lipoate. $\mathrm{O}$, Radioactivity; $\bigcirc, E_{330}$.

\section{Uptake of lipoate and other substrates}

The rate and extent of uptake by the lipoate-grown cells (Fig. 3) follow the order: acetate > octanoate $>$ lipoate. The uptakes of these three substrates were similar, and very low, when the cells were grown in the $0.4 \%(\mathrm{w} / \mathrm{v})$ glucose medium.

\section{Oxidation}

The rates of oxygen uptake by the pseudomonad with lipoate and its analogues are summarized in Table $\mathrm{I}$. The comparatively low rates of cell oxidation on bisnor- and tetranorlipoate are consistent with the inability of the bacterium to grow on these two chainshortened analogues.

Figure 4 shows the rates of bacterial oxidation of different concentrations of lipoate and of octanoate. At low concentrations, octanoate is apparently a more favourable substrate than lipoate, though in an earlier experiment (Shih et al. 1972) the oxidation rates of both substrates were similar when a much higher concentration $(\approx 3.3 \mathrm{~mm})$ of lipoate was added.

\section{${ }^{14} \mathrm{CO}_{2}$ production}

The production of ${ }^{14} \mathrm{CO}_{2}$ from $\left[\mathrm{I}, 6-{ }^{14} \mathrm{C}_{2}\right]$ lipoate and from $\left[\mathrm{I}^{-14} \mathrm{C}\right]$ octanoate by either intact or sonicated bacterial cells is shown in Fig. 5. $\mathrm{CO}_{2}$ was produced at a faster rate from octanoate than from lipoate, consistent with the higher rate of oxygen uptake with the simple alkanoic acid as substrate (cf. Fig. 4).

\section{Sulphur sources}

A 'sulphur-free' acetate medium provides growth only to an $E_{650}$ of 0.15 ; the traces of sulphur compounds supplied enhanced growth in all cases. The effect of lipoate and its analogues is always delayed to give a diphasic growth of the bacterium, and tetranor-lipoate always first inhibits, then stimulates, growth earlier than the other two analogues. A growth 


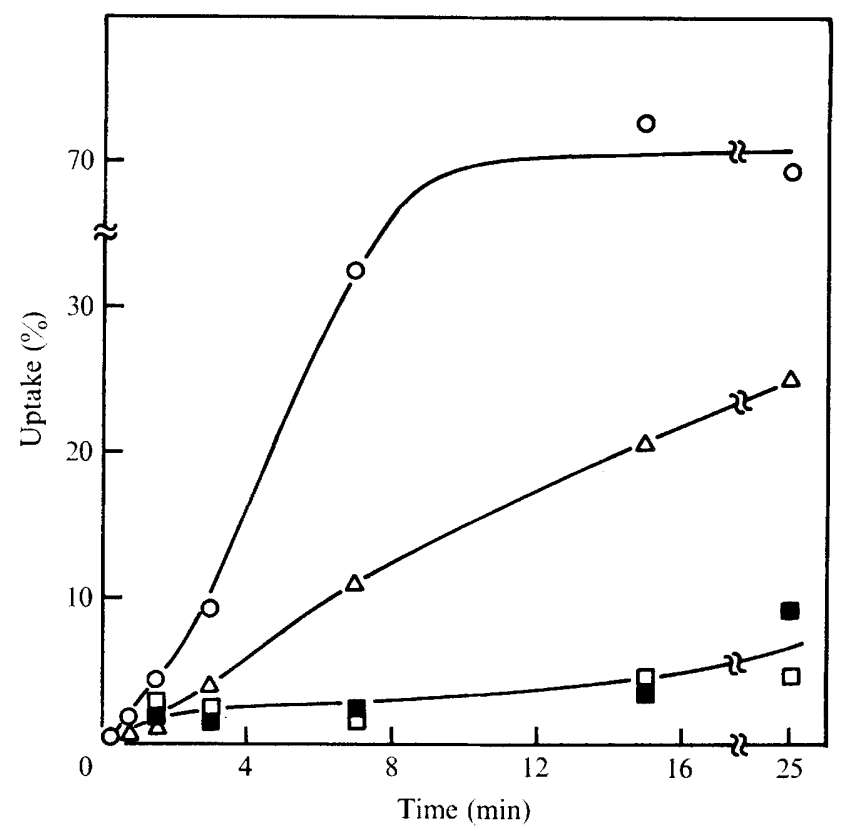

Fig. 3. Rate of uptake of $\left[{ }^{14} \mathrm{C}\right]$ lipoate $(O)$, $\left[{ }^{14} \mathrm{C}\right]$ octanoate $(\triangle)$, and $\left[{ }^{14} \mathrm{C}\right]$ acetate $(\square)$ by washed suspensions of bacteria grown in lipoate medium. On glucose $(\boldsymbol{\square})$ medium, the rates for all three substrates were identical.

Table I. Rate of oxygen uptake by Pseudomonas putida LP with lipoate or its analogues

$\begin{array}{lcc}\text { Substrate }(5 \mu \mathrm{mol}) & \begin{array}{c}\text { Oxygen uptake* } \\ \text { (nmol } / \mathrm{min})\end{array} & \text { Relative rate } \\ \text { Lipoate } & 67 \cdot 4 & 100 \\ \text { Bisnor-lipoate } & \mathrm{I} \cdot 7 & 2 \cdot 5 \\ \text { Tetranor-lipoate } & 4 \cdot 0 & 5 \cdot 9\end{array}$

The cells were harvested from a two-day-old culture in $0.4 \%$ (w/v) lipoate medium.

* The rate was obtained by subtracting the endogenous rate, $5.9 \mathrm{nmol} / \mathrm{min}$, from the measured rate, with $5 \mu \mathrm{mol}$ of substrate. The final volume of incubation mixture was $\mathrm{I} \cdot 5 \mathrm{ml}$, and incubation was at $30^{\circ} \mathrm{C}$.

equivalent to an $E_{650}$ of 0.5 unit can always be provided by acetate plus traces of any lipoate analogue, while 0.8 to $\mathrm{I} \cdot 0$ unit is provided by acetate plus traces of L-cystine, L-cysteine or sulphate. L-Cystine is the best source of sulphur tested in terms of the rate of growth and maximal growth attained.

The growth of the pseudomonad in lipoate medium containing $0.2 \%(\mathrm{w} / \mathrm{v})$ ammonium sulphate reached an $E_{650}$ maximum of 0.7 in $36 \mathrm{~h}$, while no growth was observed in either bisnor-lipoate or tetranor-lipoate medium containing $0.2 \%$ ammonium sulphate. These results are similar to those obtained with the pseudomonad in the presence of lipoate or its analogues without additional sulphate in the medium.

\section{Enzymic activities in the cell-free extracts}

Three different enzymic activities present in the cell-free extracts prepared from the pseudomonad grown on various carbon sources were determined (Table 2). The specific 


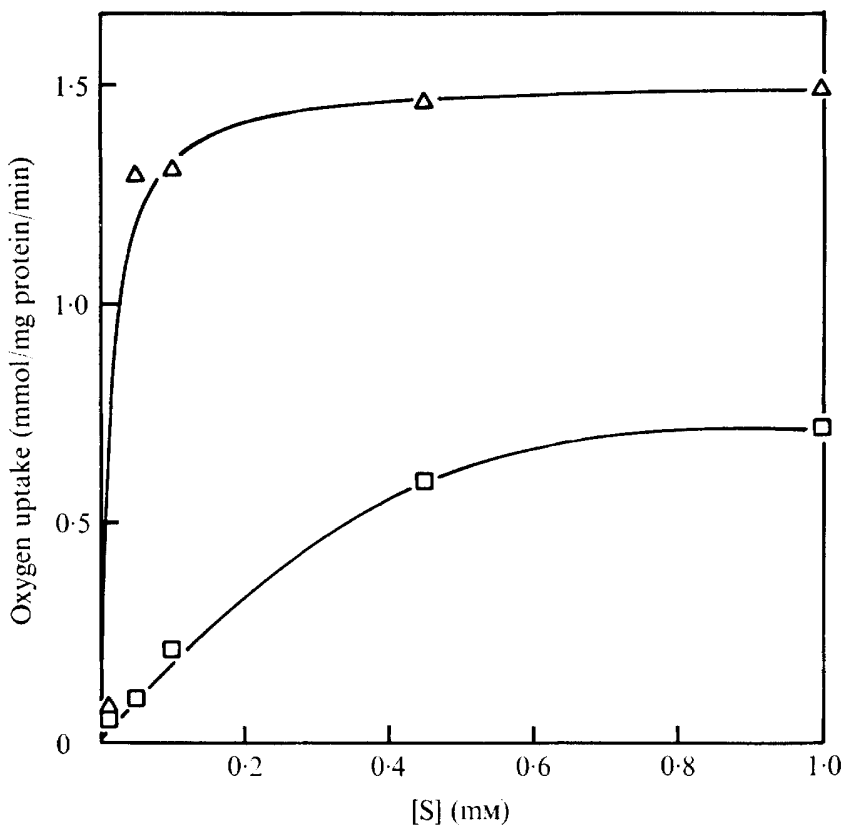

Fig. 4. Rate of oxygen uptake by bacteria with varying concentrations of lipoate $(\square)$ or octanoate $(\triangle)$.

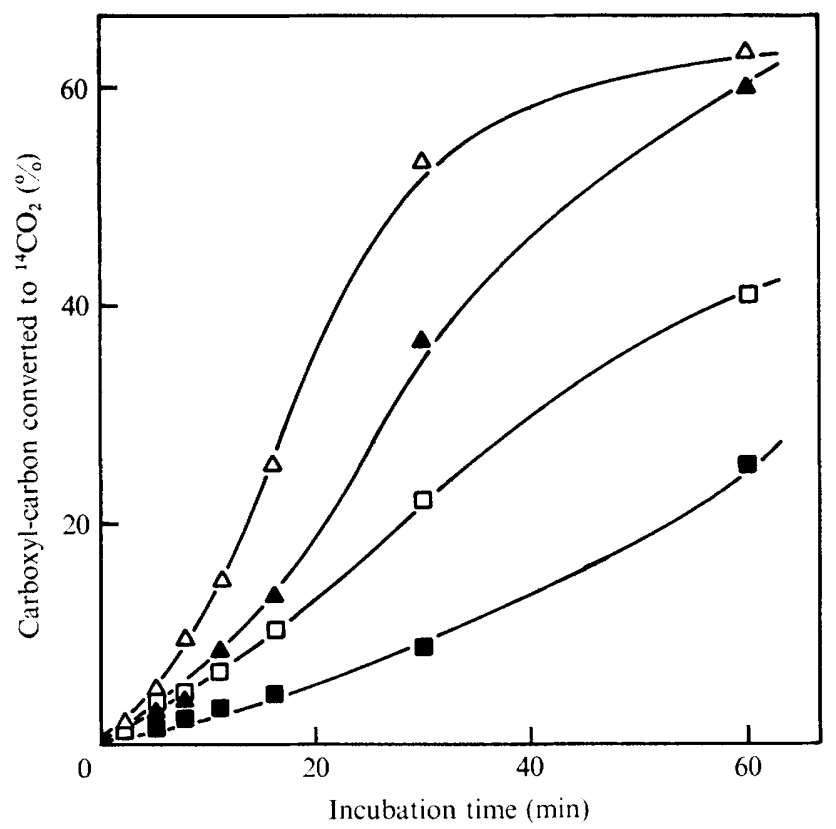

Fig. 5. Rate of ${ }^{14} \mathrm{CO}_{2}$ production by intact (open symbols) and by sonicated (solid symbols) bacteria with $\left[\mathrm{I}^{-14} \mathrm{C}\right]$ lipoate $(\square, \boldsymbol{\square})$ or $\left[\mathrm{I}-{ }^{14} \mathrm{C}\right] \operatorname{octanoate}(\triangle, \boldsymbol{\Lambda})$. 
Table 2. Activities of three enzymes in Pseudomonas putida LP grown in media containing different carbon sources

\begin{tabular}{|c|c|c|c|c|c|c|}
\hline \multirow[b]{2}{*}{ Carbon source } & \multicolumn{2}{|c|}{ Acyl-CoA synthetase } & \multicolumn{2}{|c|}{ Isocitrate lyase } & \multicolumn{2}{|c|}{ Malate synthase } \\
\hline & $\begin{array}{l}\mathrm{IO}^{-6} \times \\
\text { Specific } \\
\text { activity }\end{array}$ & $\begin{array}{l}\text { Relative } \\
\text { activity }\end{array}$ & $\begin{array}{l}10^{-6} \times \\
\text { Specific } \\
\text { activity }\end{array}$ & $\begin{array}{l}\text { Relative } \\
\text { activity }\end{array}$ & $\begin{array}{l}\mathrm{IO}^{-5} \times \\
\text { Specific } \\
\text { activity }\end{array}$ & $\begin{array}{l}\text { Relative } \\
\text { activity }\end{array}$ \\
\hline Lipoate & $I \cdot 40$ & 49 & $7 \cdot 6$ & 68 & $4 \cdot 36$ & 38 \\
\hline Octanoate & $2 \cdot 66$ & 93 & $7 \cdot 7$ & 69 & $6 \cdot 54$ & 56 \\
\hline Acetate & $2 \cdot 86$ & 100 & I I $\cdot$ I 4 & 100 & $11 \cdot 62$ & 100 \\
\hline Glucose & $2 \cdot 17$ & 76 & $0.7 \mathbf{I}$ & 6 & $I \cdot 75$ & I5 \\
\hline
\end{tabular}

Specific activities were measured as nmol product produced (acyl-CoA synthetase and isocitrate lyase) or substrate changed (malate synthase) per min per $\mathrm{mg}$ protein. Relative activities are based on values obtained with extracts from acetate-grown cells as 100.

activity of each enzyme is comparable to those obtained from other micro-organisms subjected to similar conditions for growth (Olson, I959; Dixon, Kornberg \& Lund, I960; Overath et al. 1969). Acyl-CoA synthetase activity was present in the bacterium grown on four different carbon sources. The activities of isocitrate lyase and malate synthase were highest in the bacterium when grown on acetate, intermediate when grown on octanoate and lipoate, and lowest when grown on glucose.

\section{DISCUSSION}

Since the bacterium catabolizes lipoate less effectively than octanoate, and it does not grow on bisnor- and tetranor-lipoate, the dithiolane ring apparently exerts considerable hindrance on the $\beta$-oxidation of the side chain. To interpret the lack of growth on the shorter-chain analogues of lipoate as sole carbon sources, at least two factors should be considered. First, the enzymic and/or transport mechanisms may not work effectively with bisnor- and tetranor-lipoate. Thus bacterial oxidation of both shorter-chain analogues is much slower than lipoate (cf. Table 3). In the study of transport, the uptake of lipoate by the bacterium is already quite slow (cf. Fig. 3).

A second factor is that in the lipoate medium, the sulphur:carbon ratio is $I: I \cdot 5$. This is far too high to be a balanced medium, which would approximate cell composition. Common bacterial cells contain sulphur and carbon at a weight ratio in the order of I:50 (Ribbons, 1970). Therefore, the bacteria degrade much more of the side chain for carbon and leave most of the dithiolane ring intact. In the cases of bisnor- and tetranor-lipoate, the sulphur: carbon ratios ( $I: I \cdot I$ and $I: 0 \cdot 75$, respectively) are far more undesirable, if not toxic, for the pseudomonad, which is a common soil bacterium that does not usually grow in extreme conditions. To study extensive degradation of the shorter-chain analogues of lipoate might require the selection of appropriate mutants, a practice which has been used to study the growth of Escherichia coli on short-chain fatty acids (Overath et al. 1969; Salanitro \& Wegener, I97I).

Compared with that of acetate and octanoate, the uptake of lipoate by the bacterium is very slow (cf. Fig. 3). This may indicate that there is no effective transport system for lipoate in this bacterium. Since the uptake patterns for acetate, octanoate and lipoate are similar in either lipoate- or glucose-grown cells, two conclusions can be drawn. First, the transport of lipoate is not inducible. Second, the transport of acetate or octanoate is not enhanced or induced by growing in lipoate medium, even though acetate uptake in acetate-grown 
E. coli (Wagner, Odom \& Briggs, 1972) and octanoate uptake in octanoate-grown Pseudomonas oleovorans (Toscano \& Hartline, 1973) are inducible. The uptakes of acetate and octanoate observed here may be at the constitutive level in the cell but could conceivably be induced to a higher level if cells were grown in acetate or octanoate, respectively.

Bacterial degradation of octanoate is faster than that of lipoate when $\mathrm{O}_{2}$ utilization (Fig. 4) or $\mathrm{CO}_{2}$ production (Fig. 5) are compared at varying concentrations of the substrates with intact and sonicated cells.

Lipoate and its analogues do provide sulphur for bacterial growth, an evidence for some ring-degradation, but they are not as effective sources as some other compounds. The most effective source tested is L-cystine, which, as with lipoate and analogues, contains a disulphide bond. Obviously, the bacterium can metabolize the disulphide bond at varying efficiencies, depending upon the particular structures involved. However, the reason for the delayed enhancement of bacterial growth by lipoate and analogues is not clear, though the results are reproducible. When the cells are grown in media containing lipoate or analogues, with the addition of excess sulphur as ammonium sulphate, the growth achieved is similar to that in the absence of the inorganic sulphate. Thus derivation of sulphur from lipoate and its analogues is not limiting.

Utilization of relatively large amounts of acetate, which can be derived from the $\beta$ oxidation of lipoate as the carbon source for the growing pseudomonad, should require the operation of the glyoxylate cycle (Kornberg \& Madsen, I958). This cycle is repressed by the presence of glucose, a phenomenon commonly known as catabolite repression (Magasanik, I96I; Kornberg, I966). Our results (Table 2) show that two glyoxylate-cycle enzymes, isocitrate lyase and malate synthase, were, indeed, repressed during growth on glucose, but were more active when the bacterium was grown on the other three compounds. The acylCoA synthetase was active in the pseudomonad grown on all four different carbon sources, though an inducible enzyme was found in E. coli (Overath et al. 1969). Activation of fatty acids is required by the bacterium for various functions, such as biosynthesis of complex lipids (Massaro \& Lennarz, 1965), and is not functionally restrictive to $\beta$-oxidation. AcylCoA synthetase may therefore be produced constitutively in this pseudomonad and not be sensitive to the carbon source supplied to the bacterium.

In the present work, the catabolism of lipoate has been compared with that of octanoate in $P$. putida LP. However, many strains of $P$. putida do not grow on lipoate (Shih et al. 1972) but are able to grow on octanoate (Stanier, Palleroni \& Doudoroff, I966). Apparently, the LP strain is unique in its ability not only to $\beta$-oxidize fatty acid chains, including the one of lipoate, but also to degrade sufficient quantities of the dithiolane ring to derive the sulphur.

This investigation was supported in part by research grants AM-0872I and AM-I2224, and Career Research Award K6-AM-I6, 6I2 (to L.D.W.), from the National Institute of Arthritis, Metabolism and Digestive Diseases, U.S. Public Health Service, and in part by funds made available through the State University of New York. M.L.R. was on leave of absence from the Departmento de Quimica, Universidad Nacional de Colombia, Bogota, Colombia. We thank Dr P. B. Williams, who prepared some of the compounds. 


\section{REFERENCES}

ACKER, D. S. \& WAYNE, W. J. (I957). Synthesis of racemic, optically active and radioactive $\alpha$-lipoic acids. Journal of the American Chemical Society 79, 6483-6487.

Claeson, G. (1955). I,2-Dithiolane-3-carboxylic acid. Acta chemica scandinavica 9, I78-180.

Cohen, G. N. \& Rickenserg, H. V. (1956). Concentration specifique reversible des amino acides chez Escherichia coli. Annales de l'Institut Pasteur 9r, 693-720.

Dixon, G. H. \& Kornberg, H. L. (1959). Assay methods for key enzymes of the glyoxylate cycle. Biochemical Journal 72, 3 P.

Dixon, G. H., Kornberg, H. L. \& Lúnd, P. (1960). Purification and properties of malate synthetase. Biochimica et biophysica acta 4r, 217-233.

EgGereR, H. \& KLetTE, A. (1967). Über das Katalyseprinzip der Malatsynthase. European Journal of Biochemistry I, 447-475.

KORNBERG, H. L. (1966). The role and control of the glyoxylate cycle in Escherichia coli. Biochemical Journal 99, I-II.

KornBerg, H. L. \& MADSEN, N. B. (1958). The metabolism of $\mathrm{C}_{2}$ compounds in micro-organisms. Biochemical Journal 68, 549-557.

KumaGaYa, M. \& KaSUGA, K. (1963). Syntheses of 3-( $\beta$-carboxyethyl)-1,2-dithiolane derivatives. Japanese Chemical Journal 84, 44-46.

Lowry, O. H., Rosebrough, N. J., Farr, A. L. \& Randall, R. J. (I95I). Protein measurement with the Folin phenol reagent. Journal of Biological Chemistry 193, 265-275.

Magasanik, B. (1961). Catabolite repression. Cold Spring Harbor Symposia on Quantitative Biology 26, 249-256.

Massaro, E. J. \& Lennarz, W. J. (1965). The partial purification and characterization of a bacterial fatty acyl coenzyme A synthetase. Biochemistry 4, 85-90.

Olson, J. A. (1959). The purification and properties of yeast isocitric lyase. Journal of Biological Chemistry 234, 5-IO.

Overath, P., Pauli, G. \& Schairer, H. U. (I969). Fatty acid degradation in Escherichia coli. An inducible acyl-CoA synthetase, the mapping of old mutations, and the isolation of regulatory mutants. European Journal of Biochemistry 7, 559-574.

Pritchard, A. B., McCormick, D. B. \& Wright, L. D. (I970). Chemical syntheses of ${ }^{14} \mathrm{C}-\alpha$-lipoic acid. In Methods in Enzymology, vol. I8A, pp. 273-275. New York: Academic Press.

Risions, D. W. (1970). Quantitative relationships between growth media constituents and cellular yields and composition. In Methods in Enzymology, vol. 3A, pp. 297-304. New York: Academic Press.

Salanitro, J. P. \& Wegener, W. S. (I97I). Growth of Escherichia coli on short-chain fatty acids: growth characteristics of mutants. Journal of Bacteriology 108, 885-892.

Shih, J. C. H., Williams, P. B., Wright, L. D. \& MCCormick, D. B. (I974). Properties of lipoic acid analogs. Journal of Heterocyclic Chemistry II, I I9-123.

ShIH, J. C. H., Wright, L. D. \& McCormick, D. B. (1972). Isolation, identification and characterization of a lipoate-degrading pseudomonad and of a lipoate catabolite. Journal of Bacteriology 112, 1043-105I.

Stanier, R. Y., Palleroni, N. J. \& Doudoroff, M. (1966). The aerobic pseudomonads. A taxonomic study. Journal of General Microbiology 43, 225-23I.

Toscano, W. A. \& Hartuine, R. A. (1973). Transport of octanoate by Pseudomonas oleovorans. Journal of Bacteriology I16, 54I-547.

WAGNER, C., ODOM, R. \& BRIGGS, W. T. (1972). The uptake of acetate by Escherichia coli w. Biochemical and Biophysical Research Communications 47, 1036-1040.

WLADISLAW, B. (1957). Syntheses of lower homologues of 6,8-thioctic acid. Chemistry and Industry, 263-264.

YANG, C. S. \& MCCormick, D. B. (1967). Degradation and excretion of riboflavin in the rat. Journal of Nutrition 93, 445-453. 